OPEN ACCESS

Edited by: Jeremy Foster, New England Biolabs, United States

Reviewed by:

J. L. Pennock,

The University of Manchester,

United Kingdom

Shi Yan,

University of Veterinary Medicine

Vienna, Austria

${ }^{*}$ Correspondence:

William Harnett

w.harnett@strath.ac.uk

${ }^{\dagger}$ These authors share first authorship

Specialty section: This article was submitted to Neglected Tropical Diseases, a section of the journal Frontiers in Tropical Diseases

Received: 01 September 2021 Accepted: 17 November 2021 Published: 14 December 2021

Citation:

Buitrago G, Duncombe-Moore J, Harnett MM and Harnett W (2021) Mini

Review: Structure and Function of Nematode PhosphorylcholineContaining Glycoconjugates.

Front. Trop. Dis. 2:769000. doi: 10.3389/fitd.2021.769000

\section{Mini Review: Structure and Function of Nematode Phosphorylcholine- Containing Glycoconjugates}

\author{
Geraldine Buitrago ${ }^{1 \dagger}$, Josephine Duncombe-Moore ${ }^{2 \dagger}$, \\ Margaret M. Harnett ${ }^{2}$ and William Harnett ${ }^{1 *}$ \\ ${ }^{1}$ Strathclyde Institute for Pharmacy and Biomedical Sciences, University of Strathclyde, Glasgow, United Kingdom, \\ 2 Institute of Infection, Immunity and Inflammation, University of Glasgow, Glasgow, United Kingdom
}

An unusual aspect of the biology of nematodes is the covalent attachment of phosphorylcholine (PC) to carbohydrate in glycoconjugates. Investigation of the structure of these molecules by ever-increasingly sophisticated analytical procedures has revealed that PC is generally in phosphodiester linkage with C6 of $\mathrm{N}$-acetylglucosamine (GlcNAc) in both $N$-type glycans and glycosphingolipids. Up to five PC groups have been detected in the former, being located on both antenna and core GlcNAc. The PC donor for transfer to carbohydrate appears to be phosphatidylcholine but the enzyme responsible for transfer remains to be identified. Work primarily involving the PC-containing Acanthocheilonema viteae secreted product ES-62, has shown that the PC attached to nematode $\mathrm{N}$-glycans possesses a range of immunomodulatory properties, subverting for example, pro-inflammatory signalling in various immune system cell-types including lymphocytes, mast cells, dendritic cells and macrophages. This has led to the generation of PC-based ES-62 small molecule analogues (SMAs), which mirror the parent molecule in preventing the initiation or progression of disease in mouse models of a number of human conditions associated with aberrant inflammatory responses. These include rheumatoid arthritis, systemic lupus erythematosus and lung and skin allergy such that the SMAs are considered to have widespread therapeutic potential.

Keywords: anti-inflammatory drug development, ES-62, glycoconjugate, immunomodulation, nematode, phosphorylcholine

\section{INTRODUCTION}

During the human-infectious stage of the helminthic life cycle, parasites engage in a series of actions designed to evade the host immune response (1). Initially, defensive manoeuvres such as tegument moulting and membrane turnover were described $(2,3)$, but it is now understood that parasites can further promote their longevity by directly manipulating host systems, via the release of biologically active excretory/secretory molecules $(\mathrm{E} / \mathrm{S})$. The evolution of molecular parasitology in recent years has enabled an increasingly precise characterisation of these molecules. 
Herein we examine nematode phosphorylcholine (PC)containing glycoconjugates, in the context of the structure and function of these unique molecules. The first suggestion of the relevance of PC in host-parasite interactions came with discovery of PC on nematode carbohydrate-containing molecules, and also anti-PC antibodies in rats exposed to Nippostrongylus brasiliensis and Haemonchus contortus, following anecdotal reports of similar results from Ascaris suum-infected rats (4). In vivo studies revealed anti-PC antibody complexes were in fact abundant in the sera of mice exposed to Brugia malayi and $B$. pahanghi, as well as jirds, chimpanzees and human subjects suffering filarial parasitosis (5-10). Analysis of the E/S profile of the adult rodent filarial nematode Acanthocheilonema viteae revealed that it is dominated by one $\mathrm{PC}$-containing glycoprotein, ES-62 $(4,11)$. Homologues of this protein have since been detected in other filarial and also non-filarial nematodes species, although it is unknown whether all of these ES-62 homologues contain PC groups (12-17).

\section{STRUCTURES OF THE A. viteae PC-GLYCANS}

ES-62 is the most characterised of the PC-bearing helminthic molecules, and accordingly the one which forms the basis for most of our understanding of the structure and function of nematode PC-glycans. ES-62 originates from the anterior oesophageal cells of $A$. viteae as a homotetrameric protein $(18,19)$. By subjecting ES-62 to $N$-glycosidase F, it was demonstrated that PC is attached to the protein backbone via $N$-linked glycans, a finding confirmed by examination of ES-62 following exposure of $A$. viteae to tunicamycin, an inhibitor of $N$-type glycosylation $(20,21)$. Monomeric ES-62 contains four potential $N$-linked glycosylation sites at residues 213, 254, 344 and 400 respectively (22). Fast atom bombardment mass spectroscopy enabled the resolution of three associated $N$-type glycan structures: a high mannose $N$-glycan
$\left(\mathrm{Man}_{5-9} \mathrm{GlcNAc}_{2}\right)$, a truncated oligosaccharide, trimmed to the trimannosyl core and fucosylated $\left(\mathrm{Fuc}_{1} \mathrm{Man}_{3} \mathrm{GlCNAc}_{3-6}\right)$, and a novel glycan, which is similarly truncated and may be fucosylated or not, and which acquires between 1-4 antenna GlcNAc residues $\left(\right.$ Fuc $_{0-1} \mathrm{Man}_{3} \mathrm{GlcNAc}_{3-6}$ ) to which PC is attached (Figure 1). More recently, employment of nano-flow liquid chromatography followed by electrospray ionization mass spectrometry by North et al. (23) revealed that each of the $N$-linked glycosylation sites of ES-62 can accommodate PC-bearing glycans. Furthermore, each glycan's structure was determined to contain up to five PC groups: four from antennary GlcNAc residues, and a fifth attaching to core GlcNAc. It has been estimated that the secreted tetrameric ES-62 can bear up to 72 PC groups, with the molecule's structure ensuring the bulk of these are positioned for receptor engagement.

\section{PC-GLYCAN STRUCTURES IN OTHER SPECIES}

Molecules closely mimicking the original ES-62 PC-glycan structures (Figure 1) have been detected in anthropophilic filarial species B. malayi, Onchocerca volvulus, Wucheria bancrofti and Loa loa, and additionally in B. pahangi (feline), O. gibsoni (bovine) and Dirofilaria immitis (canine) species (12, $13,17,19)$. Outside of filaria, these PC-glycan structures also remain relatively consistent in parasitic nematodes; thus Trichinella spiralis produces glycans which similarly appear to bear PC moieties likely attached to GlcNAc residues on a trimmed trimannosyl core, although this is followed by further GalNAc transferase activity to extend the antenna (24). A. suum ( $\mathrm{HexNAc}_{3-5} \mathrm{Hex}_{3-4} \mathrm{Fuc}_{0-1} \mathrm{PC}_{1-2}$ ) and Trichuris suis $\left(\mathrm{Hex}_{3} \mathrm{HexNAc}_{4-5} \mathrm{Fuc}_{2} \mathrm{PC}\right)$ additionally produce a number of comparable glycan structures to the ES-62 PC-glycans $(15,25)$. Fascinatingly, similar PC-modified $\mathrm{N}$-glycans have also been described in free-living species including Caenorhabditis elegans $\left(\mathrm{Hex}_{3} \mathrm{HexNAc}_{3} \mathrm{Fuc}_{0-1} \mathrm{PC}\right)$ and Pristionchus pacificus

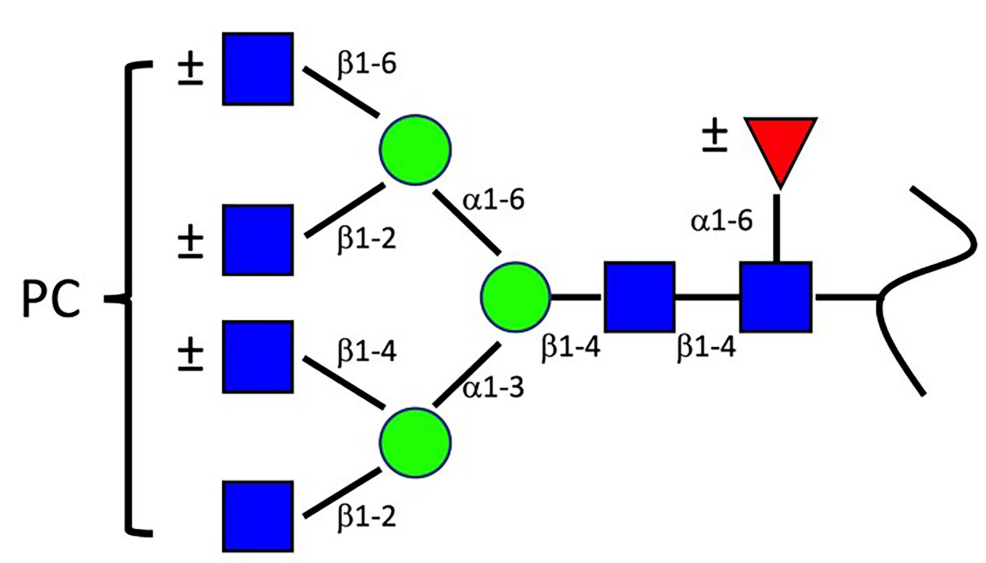

\section{PC - phosphorylcholine - Mannose - GlcNAc - Fucose}

FIGURE 1 | ES-62 PC-glycans structure. This structure, proposed by FAB-MS (22) has been conserved throughout parasitic nematode species. Later characterisation by ES/MS indicates the glycan structure can accommodate up to four antenna PC groups, with further PC attachment to core GIcNAc residues occurring (12, 22, 23). Image modified from (12). 
$\left(\mathrm{Hex}_{3} \mathrm{HexNAc}_{5} \mathrm{Fuc}_{0-1} \mathrm{PC}_{1-3}\right)$, with attachment occurring on nonreducing GlcNAc or LacDiNac motifs. This suggests that such PC-N-glycans may be conserved throughout the phylum (26, 27), although the PC-containing structures in free-living nematodes are tri-antennary rather than tetra-antennary (tetraantennary $\mathrm{N}$-glycans don't appear to be formed in free living species) as observed for ES-62. Moreover, PC-substituted glycosphingolipids have been reported in embryonic-stage $C$. elegans, as well as in $A$. viteae, O. volvulus, O. ochengi, Litomosoides sigmodontis and A. suum species (28-30).

\section{BIOSYNTHETIC PATHWAY OF PC-GLYCANS}

Employment of a combination of intracellular trafficking inhibitors, oligosaccharide processing inhibitors, pulse-chase radiolabelling experiments and FAB-MS analysis has permitted characterisation of the intracellular processing events which attach PC to newly produced glycans in A. viteae and C. elegans $(23,30-$ 33). It is within the medial Golgi that the process of PC attachment to maturing $N$-glycans occurs (Figure 2). Initially, an antennary GlcNAc residue is attached to the glycan structure by GlcNAc Transferase I. PC is subsequently transferred from a donor, likely phosphatidycholine, via a C-6 phosphodiester linkage of the antenna GlcNAc residue. Two mannose sugars are then trimmed from the core by Mannosidase II. Next, GlcNAc Transferase II adds a second terminal GlcNAc residue and then additional PC may be added. As yet, the PC-transferase enzyme involved in this process remains uncharacterised.

\section{FUNCTION OF NEMATODE PC-GLYCANS: STUDIES IN VITRO}

PC on nematode glycoproteins has immunomodulatory properties as first shown by its inhibition of lymphocyte proliferation $(34,35)$. The mechanisms behind such activity have been extensively studied using ES-62 and to a lesser degree, PC alone or conjugated to proteins such as bovine serum albumin (BSA), or small molecule analogues (SMAs) of ES-62 based on its PC moiety (Figure 3A) (36). For example, the PC-containing molecules inhibit $\mathrm{B}$ cell receptor (BCR)-stimulated phosphoinositide-3kinase (PI3K) and protein kinase C activities (35-37), as well as reducing the phosphorylation of $\operatorname{Ig} \beta$ and the adaptor Shc1 resulting in reduced Erk1/2 MAPK activation $(37,38)$. This appears to reflect that ES-62 promotes recruitment of the protein tyrosine phosphatase, SHP-1 resulting in rapid dephosphorylation of these BCR-stimulated substrates (38). Furthermore, ES-62 terminates ongoing Erk1/2 activity upon BCR stimulation by recruitment of dual specificity phosphatase Dusp2, which dephosphorylates their threonine and tyrosine activation motifs.

Such immunomodulatory actions have also been observed with innate immune system cells. Thus, like ES-62, PC-based SMAs $11 \mathrm{a}$ and 12b inhibit FceRI-mediated signalling and degranulation, as well as proinflammatory cytokine secretion

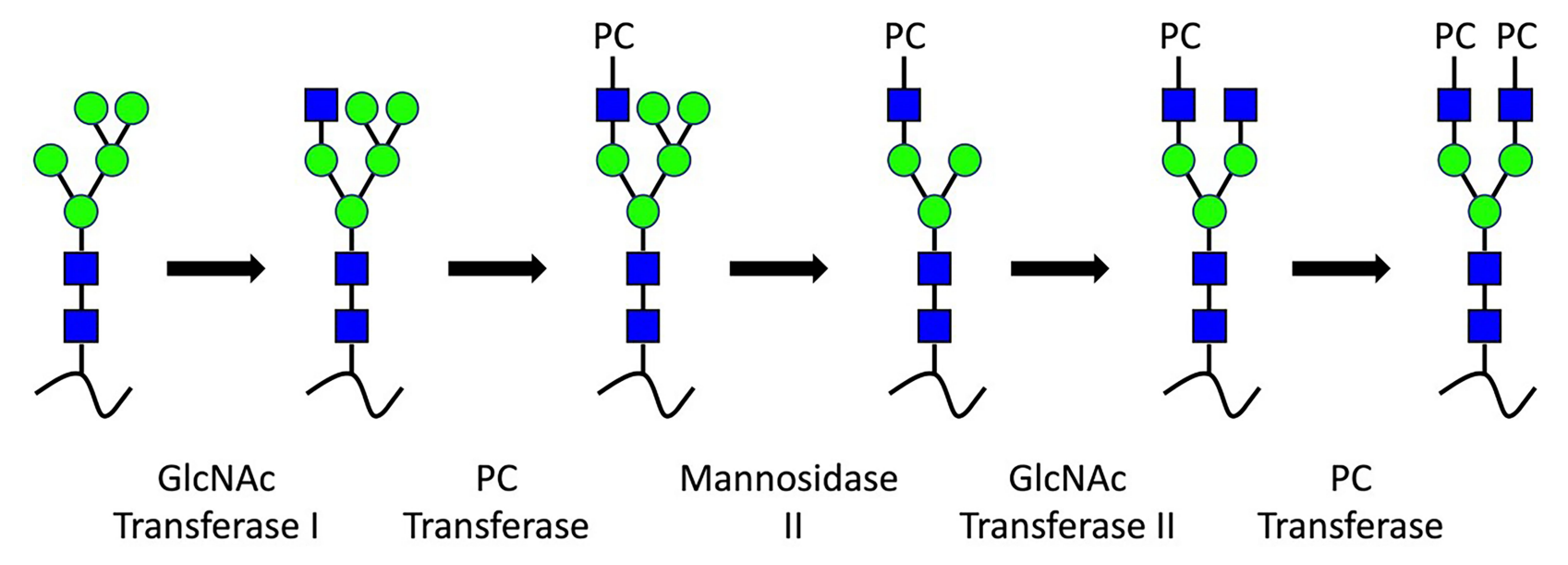

\author{
PC - phosphorylcholine \\ - Mannose \\ - GlcNAc
}

FIGURE 2 | ES-62 PC-glycans synthesis. During medial Golgi processing, a GlcNAc residue is transferred to the 3-linked mannose of the trimannosyl core. PC is transferred to this antennary GlcNAc residue by an as-yet uncharacterised transferase. Further PC moieties may be added to additional terminal or core GlcNAc. 
A

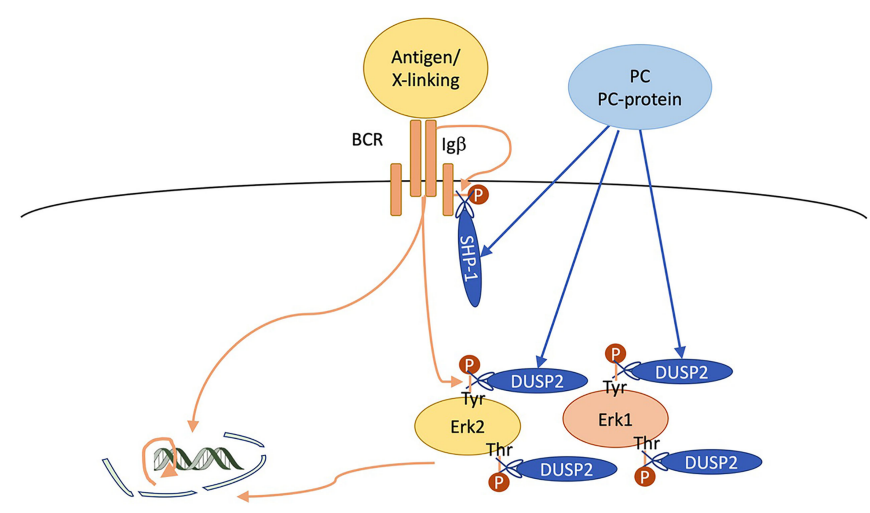

B

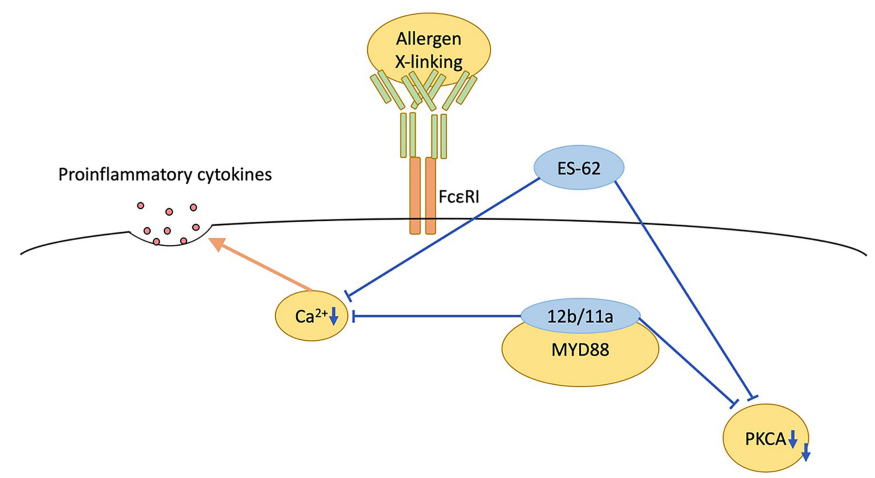

C

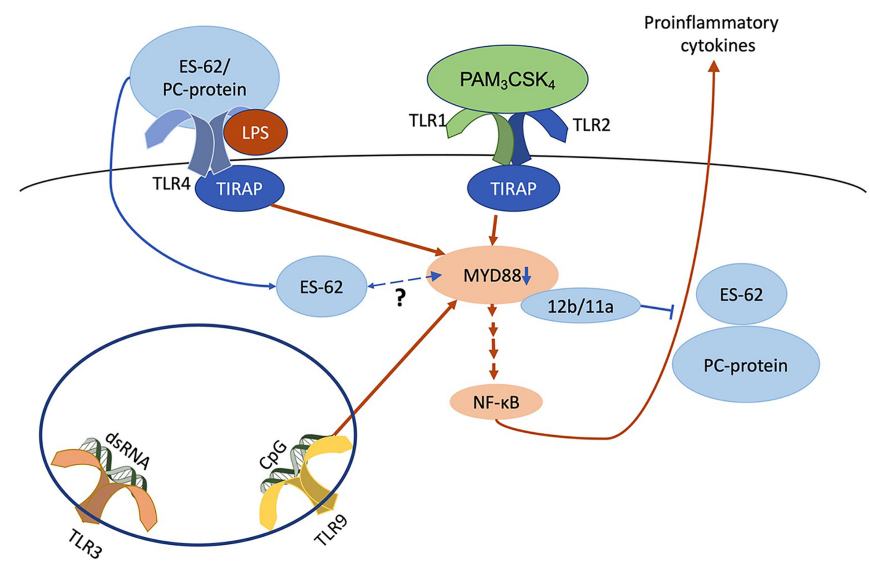

FIGURE 3 | ES-62/phosphorylcholine (PC) desensitises immune system cell signalling in vitro. (A) The B cell antigen receptor (BCR) signals via ITAM-containing lgo/ $\beta$ accessory molecules to recruit proliferative signalling pathways like the ERK MAPK cascade in a tyrosine kinase-dependent manner. PC/ES-62 desensitises the BCR both by recruiting SHP-1 to dephosphorylate Ig $\beta$ and uncouple downstream signalling and by inducing DUSP2 dephosphorylation of the TEY activation motif of ERK1/2. (B) FceRI-mediated degranulation requires calcium and PKC $\alpha$ signalling whilst, at least in some mast cell subsets, cytokine secretion also requires crosstalk with MyD88 signalling and all of these elements are targeted by PC/ES-62. (C) TLR4 homodimer and TLR1/2 heterodimer located at the cell surface on dendritic cells and macrophages signal through the adaptor proteins TIRAP and MyD88 in response to LPS and bacterial lipopeptide (e.g., PAM $\mathrm{CSKK}_{4}$ ) respectively. TLR9, which responds to unmethylated cytosine-phosphate-guanine (CpG) DNA, also signals through MyD88. MyD88 stimulates NF-kB regulated proinflammatory cytokine production. ES-62 and PC-conjugated proteins subvert TLR4-MyD88 signalling to reduce proinflammatory cytokine secretion in response to TLR1/2, TLR4 and TLR9 ligation. Small molecule analogues 11a and 12b interact directly with MyD88 thereby similarly inhibiting cytokine production. TLR3 signalling, which is MyD88independent, is not affected by these anti-inflammatory agents. ES-62 is internalised by macrophages and may also directly interact with MyD88 via its PC moieties. 
(Figure 3B) (39-42). This can in part be explained by reduced calcium mobilisation and protein kinase $\mathrm{C}$ alpha $(\mathrm{PKC} \alpha)$ protein expression, actions also reproduced by pre-treatment with $\mathrm{PC}$ BSA (39-41). Moreover, antigen-presenting cells (APCs) like dendritic cells and macrophages, that educate adaptive immunity are also desensitised in response to ES-62 and PC (Figure 3C) $(43,44)$. Thus here, PC-ovalbumin and SMAs $(11 \mathrm{a}, 12 \mathrm{~b})$ inhibit NF- $\kappa \mathrm{B}$ mediated pro-inflammatory cytokine secretion stimulated via MyD88-dependent toll-like receptors (TLRs; TLR4, LPS; TLR9, CpG; TLR1/2 heterodimer, $\mathrm{PAM}_{3} \mathrm{CSK}_{4}$ ) (43-50). ES-62 also supresses the synergistic NF- $\mathrm{BB}$-mediated pro-inflammatory cytokine secretion observed in response to these stimuli when tested in combination with interferon gamma (IFN $\gamma)(44,51)$. In contrast, TLR3 signalling, which is independent of MyD88, is unaffected by PC-ovalbumin or ES$62(43,44,52-54)$. This selectivity reflects that MyD88 protein expression is reduced in the presence of ES-62 or SMAs, 11a \& $12 \mathrm{~b}(50,55-58)$ and as this downregulation is also recapitulated in certain mast cell subsets (41) and lymphocytes (50, 55-59), it provides a unifying primary target for PC/ES-62 action in limiting chronic inflammatory responses.

PC, either as part of ES-62 or attached to ovalbumin, appears to "signal" through TLR4 $(43,44)$. Unlike LPS, the most defined TLR4 ligand, PC maintains its activity in the context of a proline to histidine substitution at position 712 on the receptor $(43,44$, $60,61)$. This residue sits within a cytoplasmic domain required for interaction with the signalling adaptor Mal (itself required for TLR4 interaction with MyD88), which suggests PC signals through a different mechanism to LPS $(62,63)$. Indeed, SMAs $11 \mathrm{a}$ and $12 \mathrm{~b}$ interact directly with the TIR domain of MyD88, inhibiting homodimer formation (56). As ES-62 is internalised in both mast cells and macrophages, it is possible that the parent molecule also interacts with MyD88 through its PC moieties $(40,64)$.

Complement is an innate mechanism that recognises microbial PAMPs and facilitates microbicidal activity; it is also intensely activated by $\mathrm{PC}$, which has bound to C-reactive protein (65-68). PC directly attached to proteins also activates complement in vitro; but complement activation drops considerably when PC is attached at the end of either synthetic flexible linkers, or importantly, to glycans such as in ES-62 (69, 70). This functionality may benefit parasitic worms by sequestering components of the complement cascade, resulting in a low complement activation state.

\section{PC IN MURINE MODELS OF DISEASE}

PC on the glycans of ES-62 is also active in vivo, for example, it alters the subclass of antibody produced in response to ES-62 in mice, in that removal of PC results in the generation of IgG2a antibodies that are absent when the intact molecule is employed (71). Moreover, exploring the potential of a potent antiinflammatory molecule like ES-62 as a biologic intervention in human disease has been dependent upon robust pre-clinical evaluation using in vivo experimentation. In fact, ES-62, and the drug-like SMAs represent the only stand-alone nematode PC-products that have been tested in vivo, although the suppression of rodent arthritis by A. suum extract is suspected to be attributed to a homologous PC-bearing molecule (72). These treatments have been demonstrated to be safely tolerated throughout the summarised experiments below, with potency illustrated in the resolution of a range of inflammatory conditions, irrespective of phenotype.

\section{Arthritis}

The performance of ES-62 has been most thoroughly described in the collagen-induced arthritis (CIA) model of rheumatoid arthritis, where it has displayed a potent ability to protect against disease development when delivered prophylactically, and to ameliorate established CIA when administered therapeutically (73-76). Induction of CIA in DBA/1 mice instigates articular inflammation dominated by Th17 cells $(77,78)$ and clinical indicators of arthritic disease, including paw thickness, erythema and loss of function, are reduced or absent in ES-62-treated mice (Figure 4), with histological analyses confirming protection against the synovial hyperplasia and cartilage erosion traditionally seen in this condition (73). In comparison to vehicle controls, ES-62-treated mice demonstrate a skewing towards IL-10-producing regulatory B cell (Breg) phenotypes, with a downregulation in effector cells bearing CD80, CD86 and TLR4/MyD88, and a dramatic curtailing of IL-17 production by Th17 and $\gamma \delta$ T cells $(58,73)$. Further molecular studies have proposed that in resolving CIA, ES-62 targets signalling cascades which drive effector T cell migration and activation. Somewhat unexpectedly, suppression of IL-22 neutralised ES-62's jointprotective effects, with the data suggesting dual pathogenic and protective roles in the initiation and established phases of disease for this cytokine: indeed, exposure to ES-62 upregulated protective IL-22 production by $\gamma \delta \mathrm{T}$ cells $(75,79)$. Most recently, it has become clear that the gut-bone marrow axis of immune regulation plays a key role in ES-62's anti-inflammatory actions, with normalisation of gut microbiota being associated with promotion of Bregs and suppression of osteoclast differentiation $(76,80)$. Treatment in the CIA model with PCBSA, SMA 11a or SMA 12b also significantly suppressed arthritic pathology $(50,55)$. Whilst SMA 11a appeared to mimic the suppression of IL-17-polarised inflammation, interestingly, SMA $12 \mathrm{~b}$ instead appeared to act predominantly via reduction of IL$12 \mathrm{p} 40$ and IL-1 $\beta$ : thus, these SMAs appeared to target differential downstream effectors of MyD88-NF- $\mathrm{KB}$ signalling.

\section{Systemic Lupus Erythematosus (SLE)}

ES-62 has displayed efficacy in two separate models of SLEinduced pathology. In characterising the renal components of disease progression, MRL/Lpr mice receiving ES-62 demonstrated a significant and consistent reduction in proteinuria, coupled with a resistance to arthritogenesis and anti-nuclear antibody (ANA) production, evidenced at termination (81). Protection against autoimmune inflammation was again associated with increased IL-10-producing Bregs in the kidneys and spleen. PC-based SMAs also proved effective in this model, with both inhibiting IL-6 responses but whilst 12b was 


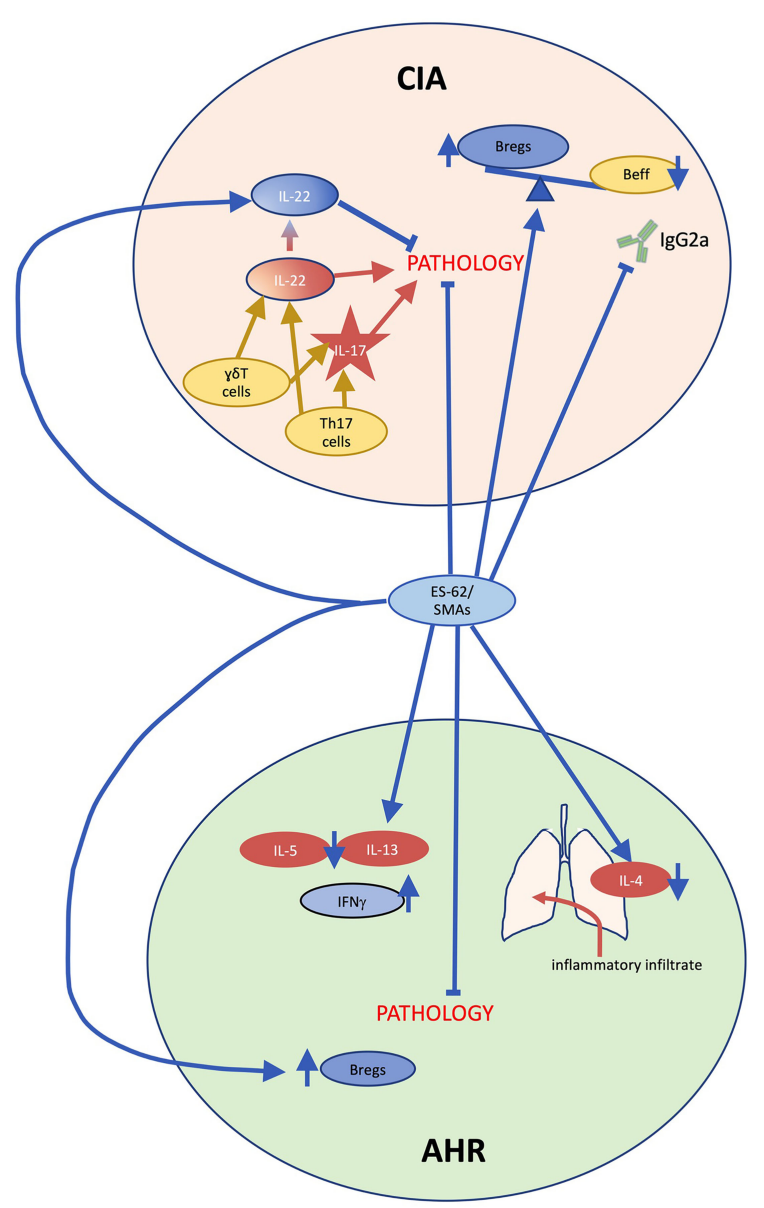

FIGURE 4 | ES-62/PC-mechanism of action in collagen-induced arthritis and ovalbumin-induced airway hyperresponsiveness. In collagen induced arthritis (CIA), during the initiation phase, $\gamma \delta \mathrm{T}$ cells and T helper (Th)17 cells secrete interleukin (IL)-17 and IL-22 causing joint pathology. By contrast, during established disease IL22 acts to limit pathology, indicating that this cytokine plays dual pathogenic and protective roles in CIA. Treatment with ES-62 or small molecule analogue (SMA) 11a inhibits IL-17 production and ES-62 promotes protective IL-22 production as well as restoring regulatory B cell (Breg) responses to counter pathogenic effector B cell (Beff) responses including collagen-specific IgG2a production, thereby substantially reducing arthritis. In ovalbumin-induced airway hyperresponsiveness (AHR), inflammatory immune system cells such as eosinophils and neutrophils infiltrate the lungs, generating IL-4 production, and a Th2 anti-inflammatory immunological phenotype is evident in immune cells in draining lymph nodes as the cells secrete IL-5 and IL-13 upon re-stimulation ex vivo. ES-62 and SMA administration reduce the infiltration of inflammatory immune cells and the former has also been shown to inhibit the ex vivo production of IL-5 and IL-13. Moreover, ES-62-activity in this model has been found to be dependent on IFN- $\gamma$ and in addition, similar to CIA, the helminth product increases IL-10-producing Bregs.

more effective in preventing ANA deposition, 11a was more potent in suppressing proteinuria (59).

In the Gld.apoE ${ }^{-/-}$model of accelerated atherosclerosis in lupus (82), mice maintained on a Western-style high cholesterol diet were continuously delivered ES-62 by osmotic pump to mimic serum levels during active infection (83). At termination, examination of aortae revealed a dramatic ES-62-mediated reduction in lesion area (approximately 60\%), which was associated with a decrease in collagen deposition and macrophage frequency. Cholesterol levels and lymphadenopathy remained unchanged. Distinct, but non-significant, trends in glomerular cellularity and proteinuria were also detected. Of note, the therapeutic effects in ES-62-treated mice were not attributable to generation of antibodies to ES-62's PC moieties despite recent findings that such antibodies, which cross-react with
PC-containing oxidised low-density lipoproteins, may prevent atherosclerosis by inhibiting lipoprotein uptake by macrophages (see below).

\section{Asthma}

Inflammatory damage in ovalbumin (OVA)-induced airway hyperresponsiveness, a mouse model of asthma, is ablated by prophylactic administration of ES-62 $(40,84)$. Administration of ES-62 robustly inhibited eosinophil, neutrophil, and lymphocyte infiltration upon inflammatory challenge (Figure 4). This is associated with a suppression of Th2-like responses, with significant reductions in IL-4 in lung tissue at termination, and downregulation of IL-13 and IL-5 and upregulation of IFN $\gamma$ production in ex vivo draining lymph node cultures. Increased expression of the regulatory $\mathrm{T}$ cell marker FOXP3 was not 
observed in ES-62-treated mice, in contrast with the mechanism reported for other helminth molecules in suppressing the OVAinduced asthma model $(85,86)$. Subcutaneous treatment with SMAs $11 \mathrm{a}$ or $12 \mathrm{~b}$ induced a similarly protective phenotype, associated with a distinct reduction in lung neutrophil and mast cell populations and in the chronic model of asthma, such protection was associated with a decrease in lung MyD88 levels and an increase in splenic Bregs (87). There was again no indication of any elevation in FOXP3 or Treg responses.

\section{Fibrotic Lung Disease}

SMAs $12 \mathrm{~b}$ and 11a have also performed strongly in the LPS- and bleomycin-induced models of fibrotic lung disease, reducing collagen deposition, structural corruption and cell infiltration to levels comparable with the dexamethasone control (88). Two additional SMAs derived from 11a (16b and AIK-29/62) were also tested, and displayed a similar potency in reduction of collagen deposition and lung tissue weight at termination.

\section{Dermatitis}

The effect of ES-62 on mast cell function was also assessed in the oxazolone sensitisation model of skin hypersensitivity (40). Treated mice displayed a $60-70 \%$ reduction in ear swelling, which correlated with an absence of TNFo, IL-3, and IL-6 mRNA. Degranulation of mast cells captured from sensitised and challenged mice treated with ES-62 was also inhibited ex vivo, although no reduction in FceRI expression was detectable, implying an interference in the activation cascade in the generation of these effects. Treatment with SMAs 11a and 12b similarly supresses ear thickening in this model, with reductions of up to $82 \%$ being measured in comparison to the negative control (50). Interestingly, no reduction in TNF $\alpha$ or IL-6 mRNA was detected, suggesting that in this model the SMAs may show some differences in mechanism to native ES-62.

\section{Obesity-Accelerated Ageing}

In this most recent study, Crowe et al. (89) report the effects of ES-62 administration on ageing-induced ill health, in the context of mice being fed a high calorie 'Westernised' diet throughout life. ES-62 was shown to protect against ageing-related liver fibrosis, with collagen deposition severely limited in both male and female ES-62-mice up to 500 days of age. Treatment with a combined dose of SMAs 11a and 12b also showed protection against liver fibrosis, particularly in female mice, whilst male mice were noted to experience reduced metabolic dysregulation over a time course of some 340 days (90). Interestingly, in male, but not female mice, treatment with ES-62 extended the median lifespan, inhibited late-ageing weight loss, and significantly reduced age-related ileal and colonic erosion, whilst normalising gut microbiota.

\section{Type 1 Diabetes, Multiple Sclerosis and Colitis}

It should be noted that ES-62 and its PC-based SMAS do not resolve all chronic inflammatory responses, failing to afford protection in mouse models of Type 1 diabetes, multiple sclerosis and colitis (91).

\section{SERENDIPITOUS INDUCTION OF ANTI-INFLAMMATORY ANTIBODIES}

Anti-PC antibodies have been found to reduce inflammation in ischemic mouse models and are plentiful in human subjects at low risk of atherosclerosis (92-94). In addition, in the context of rheumatic disease, an inverse correlation between anti-PC antibodies and, organ damage and disease activity in SLE patients has been demonstrated $(95,96)$. Although the exact mechanism(s) underlying the protective effects of anti-PC antibodies is still under investigation, anti-inflammatory and cardioprotective benefits of anti-PC antibodies in SLE and also Sjögren's syndrome and mixed connective tissue disease are associated with regulatory $\mathrm{T}$ cell polarisation, oxidised low density lipoprotein uptake inhibition and enhanced apoptotic cell clearance (96-99). Interestingly, IgM anti-PC antibodies are greatly increased in response to ES-62 in murine models of lupus and in high calorie diet (HCD)-fed mice $(82,89)$. These antibodies were not cross-reactive to oxidised low density lipoprotein nor conformed to the T15 idiotype (characteristic of most of the protective anti-PC antibodies reported) (82, 93, $100,101)$. Nevertheless, machine learning identified anti-PC IgM levels as the best predictor of effective ES-62 treatment in HCDfed mice (89). Thus, overall, it would perhaps be premature to rule out a protective role for ES-62-induced anti-PC antibodies in terms of protecting the host against obesity-accelerated ageing at this stage. Also of interest, natural IgM antibodies appear to promote a regulatory phenotype of $\mathrm{B}$ cells, which then reduce inflammation in vivo (102). Natural antibodies are secreted by B1 $\mathrm{B}$ cells independently of $\mathrm{T}$ cell stimulation, have limited diversity and recognise multiple antigens (103-107). Indeed, ES-62 stimulates B1 B cell activation in vivo and increases regulatory B cell numbers in several in vivo models $(74,76,81,87,108)$.

\section{CONCLUSION AND FUTURE DIRECTIONS}

Increasingly sophisticated analytical procedures are being applied to the elucidation of the structure of nematode PCcontaining glycoconjugates. This has revealed a general uniformity across the nematode phylum and also that these novel carbohydrate structures may have not one, but multiple, PC groups attached. PC-containing nematode glycoconjugates possess immunomodulatory properties such that they are potentially therapeutic but full exploitation of this with respect to PC-containing glycoproteins such as ES-62 is handicapped by an inability to produce fully active recombinant forms, as no convenient protein expression system exists that encodes the (unidentified) requisite PC transferase enzyme (109-112). PCbased SMAs can alternatively circumvent this problem and may represent the form in which active nematode molecules make it to the clinic. At the same time, three issues which remain to be resolved are: (i) increased understanding of the molecular complexity underlying the range of immunomodulatory activities of secreted PC-containing proteins like ES-62. For example, we have learned of how ES-62 is reliant on expression 
of TLR4 for PC-dependent activity against macrophages and dendritic cells (46), but it appears that additional receptors may exist in cells such as lymphocytes with which ES-62 can interact in a PC-dependent manner (66). Moreover, ES-62's modulation of immune cell function can be associated with effects on multiple cell signalling pathways, e.g., in mast cells, ES-62 impacts on cross talk amongst TLR4-, ST2- and FceRI-dependent pathways (113), highlighting the level of complexity that may need to be dissected. (ii) a greater understanding of the function of PC-glycoconjugates found as internal rather than secreted products of nematodes this is unlikely to relate to immunomodulation because as described earlier the structures are found within free-living species in addition to parasitic species. One possibility relates to growth and development. Consistent with this, chemical blockage of production of PC-containing glycosphingolipids by targeting enzymes upstream of PC addition impairs embryonic development in C. elegans, although a direct role for PC has not been shown (114). (iii) the identity of the aforementioned nematode enzyme which transfers PC to carbohydrate - as such

\section{REFERENCES}

1. Brooker S, Bethony J, Hotez PJ. Human Hookworm Infection in the 21st Century. Adv Parasitol (2004) 58:197-288. doi: 10.1016/S0065-308X(04) 58004-1

2. Recker M, Nee S, Bull PC, Kinyanjui S, Marsh K, Newbold C, et al. Transient Cross-Reactive Immune Responses can Orchestrate Antigenic Variation in Malaria. Nature (2004) 429:555-8. doi: 10.1038/nature02486

3. Leow CY, Willis C, Hofmann A, Jones MK. Structure-Function Analysis of Apical Membrane-Associated Molecules of the Tegument of Schistosome Parasites of Humans: Prospects for Identification of Novel Targets for Parasite Control. Br J Pharmacol (2015) 172:1653-63. doi: 10.1111/ bph.12898

4. Péry P, Petit A, Poulain J, Luffau G. Phosphorylcholine-Bearing Components in Homogenates of Nematodes. Eur J Immunol (1974) 4:637-9. doi: 10.1002/eji.1830040914

5. Forsyth KP, Mitchell GF, Copeman DB. Onchocerca Gibsoni: Increase of Circulating Egg Antigen With Chemotherapy in Bovines. Exp Parasitol (1984) 58:41-55. doi: 10.1016/0014-4894(84)90019-5

6. Forsyth KP, Spark R, Kazura J, Brown GV, Peters P, Heywood P, et al. A Monoclonal Antibody-Based Immunoradiometric Assay for Detection of Circulating Antigen in Bancroftian Filariasis. J Immunol (1985) 134:1172.

7. Lal RB, Paranjape RS, Briles DE, Nutman TB, Ottesen EA. Circulating Parasite Antigen(s) in Lymphatic Filariasis: Use of Monoclonal Antibodies to Phosphocholine for Immunodiagnosis. J Immunol (1987) 138:3454.

8. Maizels RM, Burke J, Denham DA. Phosphorylcholine-Bearing Antigens in Filarial Nematode Parasites: Analysis of Somatic Extracts, in-Vitro Secretions and Infection Sera From Brugia Malayi and B. Pahangi. Parasite Immunol (1987) 9:49-66. doi: 10.1111/j.1365-3024.1987.tb00488.x

9. Weiss N, van Den Ende MC, Albiez EJ, Barbiero VK, Forsyth K, Prince AM. Detection of Serum Antibodies and Circulating Antigens in a Chimpanzee Experimentally Infected With Onchocerca Volvulus. Trans $R$ Soc Trop Med Hyg (1986) 80:587-91. doi: 10.1016/0035-9203(86)90150-1

10. Wenger JD, Forsyth KP, Kazura JW. Identification of Phosphorylcholine Epitope-Containing Antigens in Brugia Malayi and Relation of Serum Epitope Levels to Infection Status of Jirds With Brugian Filariasis. Am J Trop Med Hyg (1988) 38:133-41. doi: 10.4269/ajtmh.1988.38.133

11. Harnett W, Worms MJ, Kapil A, Grainger M, Parkhouse RME. Origin, Kinetics of Circulation and Fate In Vivo of the Major Excretory-Secretory Product of Acanthocheilonema Viteae. Parasitology (1989) 99:229-39. doi: $10.1017 /$ S0031182000058686

12. Haslam SM, Houston KM, Harnett W, Reason AJ, Morris HR, Dell A. Structural Studies of N-Glycans of Filarial Parasites. Conservation of structures are absent from mammals, this enzyme if identified could offer a potential novel drug target. Interestingly, we have shown previously that enzymes acting upstream of the PC transferase in C. elegans can be knocked down by RNAi and that this results in reduced transfer of PC to proteins (115). We believe this approach could be employed in investigating the identity of the PC transferase when applied to genes of likely related function based on sequence homology in nematode genomes. Similarly, CRISPR (112) knockdown of potential related genes offers a more recent but similar approach, as do proteomics approaches focusing on the site of PC transfer, the Golgi. Of benefit to these analyses should be an in vitro assay of PC transferase activity developed by Cipollo and colleagues (33).

\section{AUTHOR CONTRIBUTIONS}

All authors listed have made a substantial, direct, and intellectual contribution to the work, and approved it for publication.

Phosphorylcholine-Substituted Glycans Among Species and Discovery of Novel Chito-Oligomers. J Biol Chem (1999) 274:20953-60. doi: 10.1074/ jbc.274.30.20953

13. Wuhrer M, Rickhoff S, Dennis RD, Lochnit G, Soboslay PT, Baumeister S, et al. Phosphocholine-Containing, Zwitterionic Glycosphingolipids of Adult Onchocerca Volvulus as Highly Conserved Antigenic Structures of Parasitic Nematodes. Biochem J (2000) 348 Pt 2:417-23. doi: 10.1042/ bj3480417

14. Deehan MR, Goodridge HS, Blair D, Lochnit G, Dennis RD, Geyer R, et al. Immunomodulatory Properties of Ascaris Suum Glycosphingolipids Phosphorylcholine and Non-Phosphorylcholine-Dependent Effects. Parasite Immunol (2002) 24:463-9. doi: 10.1046/j.1365-3024.2002.00489.x

15. Pöltl G, Kerner D, Paschinger K, Wilson IB. N-Glycans of the Porcine Nematode Parasite Ascaris Suum Are Modified With Phosphorylcholine and Core Fucose Residues. FEBS J (2007) 274:714-26. doi: 10.1111/j.17424658.2006.05615.x

16. Hewitson JP, Harcus YM, Curwen RS, Dowle AA, Atmadja AK, Ashton PD, et al. The Secretome of the Filarial Parasite, Brugia Malayi: Proteomic Profile of Adult Excretory-Secretory Products. Mol Biochem Parasitol (2008) 160:821. doi: 10.1016/j.molbiopara.2008.02.007

17. Martini F, Eckmair B, Štefanić S, Jin C, Garg M, Yan S, et al. Highly Modified and Immunoactive N-Glycans of the Canine Heartworm. Nat Commun (2019) 10:75. doi: 10.1038/s41467-018-07948-7

18. Harnett W, Houston KM, Tate R, Garate T, Apfel H, Adam R, et al. Molecular Cloning and Demonstration of an Aminopeptidase Activity in a Filarial Nematode Glycoprotein. Mol Biochem Parasitol (1999) 104:11-23. doi: 10.1016/S0166-6851(99)00113-9

19. Stepek G, Auchie M, Tate R, Watson K, Russell DG, Devaney E, et al. Expression of the Filarial Nematode Phosphorylcholine-Containing Glycoprotein, ES62, Is Stage Specific. Parasitology (2002) 125:155-64. doi: $10.1017 /$ S0031182002001920

20. Harnett W, Houston KM, Amess R, Worms MJ. Acanthocheilonema Viteae: Phosphorylcholine Is Attached to the Major Excretory-Secretory Product via an N-Linked Glycan. Exp Parasitol (1993) 77:498-502. doi: 10.1006/ expr.1993.1113

21. Houston KM, Harnett W. Prevention of Attachment of Phosphorylcholine to a Major Excretory-Secretory Product of Acanthocheilonema Viteae Using Tunicamycin. J Parasitol (1996) 82:320-4. doi: 10.2307/3284169

22. Haslam SM, Khoo K-H, Houston KM, Harnett W, Morris HR, Dell A Characterisation of the Phosphorylcholine-Containing N-Linked Oligosaccharides in the Excretory-Secretory $62 \mathrm{kDa}$ Glycoprotein of Acanthocheilonema Viteae. Mol Biochem Parasitol (1997) 85:53-66. doi: 10.1016/S0166-6851(96)02807-1 
23. North SJ, Botchway K, Doonan J, Lumb FE, Dell A, Harnett W, et al. SiteSpecific Glycoproteomic Characterization of ES-62: The Major Secreted Product of the Parasitic Worm Acanthocheilonema Viteae. Glycobiology (2019) 29:562-71. doi: 10.1093/glycob/cwz035

24. Morelle W, Haslam SM, Olivier V, Appleton JA, Morris HR, Dell A. Phosphorylcholine-Containing N-Glycans of Trichinella Spiralis: Identification of Multiantennary lacdiNAc Structures. Glycobiology (2000) 10:941-50. doi: $10.1093 /$ glycob/10.9.941

25. Wilson IBH, Paschinger K. Sweet Secrets of a Therapeutic Worm: MassSpectrometric N-Glycomic Analysis of Trichuris Suis. Anal Bioanal Chem (2016) 408:461-71. doi: 10.1007/s00216-015-9154-8

26. Hanneman AJ, Rosa JC, Ashline D, Reinhold VN. Isomer and Glycomer Complexities of Core GlcNAcs in Caenorhabditis Elegans. Glycobiology (2006) 16:874-90. doi: 10.1093/glycob/cwl011

27. Yan S, Wilson IB, Paschinger K. Comparison of RP-HPLC Modes to Analyse the N-Glycome of the Free-Living Nematode Pristionchus Pacificus. Electrophoresis (2015) 36:1314-29. doi: 10.1002/elps.201400528

28. Gerdt S, Dennis RD, Borgonie G, Schnabel R, Geyer R. Isolation, Characterization and Immunolocalization of Phosphorylcholine-Substituted Glycolipids in Developmental Stages of Caenorhabditis Elegans. Eur J Biochem (1999) 266:952-63. doi: 10.1046/j.1432-1327.1999.00937.x

29. Grabitzki J, Ahrend M, Schachter H, Geyer R, Lochnit G. The PCome of Caenorhabditis Elegans as a Prototypic Model System for Parasitic Nematodes: Identification of Phosphorylcholine-Substituted Proteins. $\mathrm{Mol}$ Biochem Parasitol (2008) 161:101-11. doi: 10.1016/j.molbiopara.2008.06.014

30. Houston KM, Lochnit G, Geyer R, Harnett W. Investigation of the Nature of Potential Phosphorylcholine Donors for Filarial Nematode Glycoconjugates. Mol Biochem Parasitol (2002) 123:55-66. doi: 10.1016/S0166-6851(02) 00134-2

31. Cipollo JF, Awad A, Costello CE, Robbins PW, Hirschberg CB. Biosynthesis In Vitro of Caenorhabditis Elegans Phosphorylcholine Oligosaccharides. Proc Natl Acad Sci USA (2004) 101:3404. doi: 10.1073/pnas.0400384101

32. Houston KM, Cushley W, Harnett W. Studies on the Site and Mechanism of Attachment of Phosphorylcholine to a Filarial Nematode Secreted Glycoprotein. J Biol Chem (1997) 272:1527-33. doi: 10.1074/jbc.272.3.1527

33. Houston KM, Harnett W. Structure and Synthesis of Nematode Phosphorylcholine-Containing Glycoconjugates. Parasitology (2004) 129:655-61. doi: 10.1017/S0031182004006171

34. Lal RB, Kumaraswami V, Steel C, Nutman TB. Phosphocholine-Containing Antigens of Brugia Malayi Nonspecifically Suppress Lymphocyte Function. Am J Trop Med Hyg (1990) 42:56-64. doi: 10.4269/ajtmh.1990.42.56

35. Harnett W, Harnett MM. Inhibition of Murine B Cell Proliferation and Down-Regulation of Protein Kinase C Levels by a PhosphorylcholineContaining Filarial Excretory-Secretory Product. J Immunol (Baltimore Md 1950) (1993) 151:4829-37.

36. Pineda MA, Lumb F, Harnett MM, Harnett W. ES-62, a Therapeutic AntiInflammatory Agent Evolved by the Filarial Nematode Acanthocheilonema Viteae. Mol Biochem Parasitol (2014) 194:1-8. doi: 10.1016/ j.molbiopara.2014.03.003

37. Deehan MR, Frame MJ, Parkhouse RME, Seatter SD, Reid SD, Harnett MM, et al. A Phosphorylcholine-Containing Filarial Nematode-Secreted Product Disrupts B Lymphocyte Activation by Targeting Key Proliferative Signaling Pathways. J Immunol (1998) 160:2692-9.

38. Deehan MR, Harnett W, Harnett MM. A Filarial Nematode-Secreted Phosphorylcholine-Containing Glycoprotein Uncouples the B Cell Antigen Receptor From Extracellular Signal-Regulated Kinase-MitogenActivated Protein Kinase by Promoting the Surface Ig-Mediated Recruitment of Src Homology 2 Domain-Containing Tyrosine Phosphatase-1 and Pac-1 Mitogen-Activated Kinase-Phosphatase. J Immunol (2001) 166:7462-8. doi: 10.4049/jimmunol.166.12.7462

39. Rzepecka J, Coates ML, Saggar M, Al-Riyami L, Coltherd J, Tay HK, et al. Small Molecule Analogues of the Immunomodulatory Parasitic Helminth Product ES-62 Have Anti-Allergy Properties. Int J Parasitol (2014) 44:66974. doi: 10.1016/j.ijpara.2014.05.001

40. Melendez AJ, Harnett MM, Pushparaj PN, Wong WF, Tay HK, McSharry CP, et al. Inhibition of FceRI-Mediated Mast Cell Responses by ES-62, a Product of Parasitic Filarial Nematodes. Nat Med (2007) 13:1375-81. doi: $10.1038 / \mathrm{nm} 1654$
41. Ball DH, Tay HK, Bell KS, Coates ML, Al-Riyami L, Rzepecka J, et al. Mast Cell Subsets and Their Functional Modulation by the Acanthocheilonema Viteae Product ES-62, Mast Cell Subsets and Their Functional Modulation by the Acanthocheilonema Viteae Product ES-62. J Parasitol Res (2013) 2013:e961268. doi: 10.1155/2013/961268

42. Bell KS, Al-Riyami L, Lumb FE, Britton GJ, Poole AW, Williams CM, et al. The Role of Individual Protein Kinase C Isoforms in Mouse Mast Cel Function and Their Targeting by the Immunomodulatory Parasitic Worm Product, ES-62. Immunol Lett (2015) 168:31-40. doi: 10.1016/ j.imlet.2015.09.001

43. Goodridge HS, McGuiness S, Houston KM, Egan CA, Al-Riyami L, Alcocer MJC, et al. Phosphorylcholine Mimics the Effects of ES-62 on Macrophages and Dendritic Cells. Parasite Immunol (2007) 29:127-37. doi: 10.1111/ j.1365-3024.2006.00926.x

44. Goodridge HS, Marshall FA, Else KJ, Houston KM, Egan C, Al-Riyami L, et al. Immunomodulation via Novel Use of TLR4 by the Filarial Nematode Phosphorylcholine-Containing Secreted Product, ES-62. J Immunol (2005) 174:284-93. doi: 10.4049/jimmunol.174.1.284

45. Honda K, Yanai H, Negishi H, Asagiri M, Sato M, Mizutani T, et al. IRF-7 Is the Master Regulator of Type-I Interferon-Dependent Immune Responses. Nature (2005) 434:772-7. doi: 10.1038/nature03464

46. Jin MS, Kim SE, Heo JY, Lee ME, Kim HM, Paik SG, et al. Crystal Structure of the TLR1-TLR2 Heterodimer Induced by Binding of a TriAcylated Lipopeptide. Cell (2007) 130:1071-82. doi: 10.1016/ j.cell.2007.09.008

47. Honda K, Ohba Y, Yanai H, Negishi H, Mizutani T, Takaoka A, et al. Spatiotemporal Regulation of MyD88-IRF-7 Signalling for Robust Type-I Interferon Induction. Nature (2005) 434:1035-40. doi: 10.1038/nature03547

48. Hemmi H, Takeuchi O, Kawai T, Kaisho T, Sato S, Sanjo H, et al. A Toll-Like Receptor Recognizes Bacterial DNA. Nature (2000) 408:740-5. doi: 10.1038/ 35047123

49. Lumb FE, Doonan J, Bell KS, Pineda MA, Corbet M, Suckling CJ, et al Dendritic Cells Provide a Therapeutic Target for Synthetic Small Molecule Analogues of the Parasitic Worm Product, ES-62. Sci Rep (2017) 7:1704. doi: 10.1038/s41598-017-01651-1

50. Al-Riyami L, Pineda MA, Rzepecka J, Huggan JK, Khalaf AI, Suckling CJ, et al. Designing Anti-Inflammatory Drugs From Parasitic Worms: A Synthetic Small Molecule Analogue of the Acanthocheilonema Viteae Product ES-62 Prevents Development of Collagen-Induced Arthritis. J Med Chem (2013) 56:9982-10002. doi: 10.1021/jm401251p

51. Goodridge HS, Wilson EH, Harnett W, Campbell CC, Harnett MM, Liew FY. Modulation of Macrophage Cytokine Production by ES-62, a Secreted Product of the Filarial Nematode Acanthocheilonema Viteae. I Immunol (2001) 167:940-5. doi: 10.4049/jimmunol.167.2.940

52. Zhou ZX, Zhang BC, Sun L. Poly(I:C) Induces Antiviral Immune Responses in Japanese Flounder (Paralichthys Olivaceus) That Require TLR3 and MDA5 and Is Negatively Regulated by Myd88. PloS One (2014) 9: e112918. doi: 10.1371/journal.pone.0112918

53. Siednienko J, Gajanayake T, Fitzgerald KA, Moynagh P, Miggin SM. Absence of MyD88 Results in Enhanced TLR3-Dependent Phosphorylation of IRF3 and Increased IFN- $\beta$ and RANTES Production. J Immunol (2011) 186:2514-22. doi: 10.4049/jimmunol.1003093

54. Alexopoulou L, Holt AC, Medzhitov R, Flavell RA. Recognition of DoubleStranded RNA and Activation of NF-kb by Toll-Like Receptor 3. Nature (2001) 413:732-8. doi: 10.1038/35099560

55. Rzepecka J, Pineda MA, Al-Riyami L, Rodgers DT, Huggan JK, Lumb FE, et al Prophylactic and Therapeutic Treatment With a Synthetic Analogue of a Parasitic Worm Product Prevents Experimental Arthritis and Inhibits IL-1 $\beta$ Production via NRF2-Mediated Counter-Regulation of the Inflammasome J Autoimmun (2015) 60:59-73. doi: 10.1016/j.jaut.2015.04.005

56. Suckling CJ, Alam S, Olson MA, Saikh KU, Harnett MM, Harnett W. Small Molecule Analogues of the Parasitic Worm Product ES-62 Interact With the TIR Domain of MyD88 to Inhibit Pro-Inflammatory Signalling. Sci Rep (2018) 8:2123. doi: 10.1038/s41598-018-20388-Z

57. Pineda MA, Eason RJ, Harnett MM, Harnett W. From the Worm to the Pill, the Parasitic Worm Product ES-62 Raises New Horizons in the Treatment of Rheumatoid Arthritis. Lupus (2015) 24:400-11. doi: 10.1177/ 0961203314560004 
58. Pineda MA, McGrath MA, Smith PC, Al-Riyami L, Rzepecka J, Gracie JA, et al. The Parasitic Helminth Product ES-62 Suppresses Pathogenesis in Collagen-Induced Arthritis by Targeting the Interleukin-17-Producing Cellular Network at Multiple Sites. Arthritis Rheum (2012) 64:3168-78. doi: 10.1002/art.34581

59. Rodgers DT, Pineda MA, Suckling CJ, Harnett W, Harnett MM. Drug-Like Analogues of the Parasitic Worm-Derived Immunomodulator ES-62 Are Therapeutic in the MRL/Lpr Model of Systemic Lupus Erythematosus. Lupus (2015) 24:1437-42. doi: 10.1177/0961203315591031

60. Vogel SN, Johnson D, Perera P-Y, Medvedev A, Larivière L, Qureshi ST, et al. Cutting Edge: Functional Characterization of the Effect of the $\mathrm{C} 3 \mathrm{H} / \mathrm{HeJ}$ Defect in Mice That Lack an Lps Gene: In Vivo Evidence for a Dominant Negative Mutation. J Immunol (1999) 162:5666-70.

61. Poltorak A, He X, Smirnova I, Liu M-Y, Huffel CV, Du X, et al. Defective LPS Signaling in $\mathrm{C} 3 \mathrm{H} / \mathrm{HeJ}$ and $\mathrm{C} 57 \mathrm{BL} / 10 \mathrm{ScCr}$ Mice: Mutations in Tlr4 Gene. Science (1998) 282:2085-8. doi: 10.1126/science.282.5396.2085

62. Bovijn C, Ulrichts P, De Smet AS, Catteeuw D, Beyaert R, Tavernier J, et al. Identification of Interaction Sites for Dimerization and Adapter Recruitment in Toll/interleukin-1 Receptor (TIR) Domain of Toll-Like Receptor 4. J Biol Chem (2012) 287:4088-98. doi: 10.1074/jbc.M111.282350

63. Gay NJ, Symmons MF, Gangloff M, Bryant CE. Assembly and Localization of Toll-Like Receptor Signalling Complexes. Nat Rev Immunol (2014) 14:546-58. doi: 10.1038/nri3713

64. Harnett W, Goodridge HS, Allen JM, Harnett M. Receptor Usage by the Acanthocheilonema Viteae-Derived Immunomodulator, ES-62. Exp Parasitol (2012) 132:97-102. doi: 10.1016/j.exppara.2011.09.001

65. Agrawal A, Shrive AK, Greenhough TJ, Volanakis JE. Topology and Structure of the C1q-Binding Site on C-Reactive Protein. J Immunol (2001) 166:3998-4004. doi: 10.4049/jimmunol.166.6.3998

66. Agrawal A, Volanakis JE. Probing the C1q-Binding Site on Human C-Reactive Protein by Site-Directed Mutagenesis. J Immunol (1994) 152:5404-10.

67. Kaplan MH, Volanakis JE. Interaction of C-Reactive Protein Complexes With the Complement System. I. Consumption of Human Complement Associated With the Reaction of C-Reactive Protein With Pneumococcal CPolysaccharide and With the Choline Phosphatides, Lecithin and Sphingomyelin. J Immunol (1974) 112:2135-47.

68. Ricklin D, Hajishengallis G, Yang K, Lambris JD. Complement: A Key System for Immune Surveillance and Homeostasis. Nat Immunol (2010) 11:785-97. doi: 10.1038/ni.1923

69. Ahmed UK, Maller NC, Iqbal AJ, Al-Riyami L, Harnett W, Raynes JG. The Carbohydrate-Linked Phosphorylcholine of the Parasitic Nematode Product ES-62 Modulates Complement Activation. J Biol Chem (2016) 291:11939_ 53. doi: 10.1074/jbc.M115.702746

70. Sjöwall C, Wetterö J, Bengtsson T, Askendal A, Almroth G, Skogh T, et al. Solid-Phase Classical Complement Activation by C-Reactive Protein (CRP) Is Inhibited by Fluid-Phase CRP-C1q Interaction. Biochem Biophys Res Commun (2007) 352:251-8. doi: 10.1016/j.bbrc.2006.11.013

71. Houston KM, Wilson EH, Eyres L, Brombacher F, Harnett MM, Alexander J, et al. Presence of Phosphorylcholine on a Filarial Nematode Protein Influences Immunoglobulin G Subclass Response to the Molecule by an Interleukin-10-Dependent Mechanism. Infect Immun (2000) 68:5466-8. doi: 10.1128/IAI.68.9.5466-5468.2000

72. Rocha FAC, Leite AKRM, Pompeu MML, Cunha TM, Verri WA, Soares FM, et al. Protective Effect of an Extract From Ascaris Suum in Experimental Arthritis Models. Infect Immun (2008) 76:2736-45. doi: 10.1128/ IAI.01085-07

73. McInnes IB, Leung BP, Harnett M, Gracie JA, Liew FY, Harnett W. A Novel Therapeutic Approach Targeting Articular Inflammation Using the Filarial Nematode-Derived Phosphorylcholine-Containing Glycoprotein ES-62. J Immunol (2003) 171:2127-33. doi: 10.4049/ jimmunol.171.4.2127

74. Rodgers DT, Pineda MA, McGrath MA, Al-Riyami L, Harnett W, Harnett MM. Protection Against Collagen-Induced Arthritis in Mice Afforded by the Parasitic Worm Product, ES-62, Is Associated With Restoration of the Levels of Interleukin-10-Producing B Cells and Reduced Plasma Cell Infiltration of the Joints. Immunology (2014) 141:457-66. doi: 10.1111/imm. 12208
75. Pineda MA, Rodgers DT, Al-Riyami L, Harnett W, Harnett MM. ES-62 Protects Against Collagen-Induced Arthritis by Resetting Interleukin-22 Toward Resolution of Inflammation in the Joints. Arthritis Rheumatol (2014) 66:1492-503. doi: 10.1002/art.38392

76. Doonan J, Tarafdar A, Pineda MA, Lumb FE, Crowe J, Khan AM, et al. The Parasitic Worm Product ES-62 Normalises the Gut Microbiota Bone Marrow Axis in Inflammatory Arthritis. Nat Commun (2019) 10:1554. doi: 10.1038/s41467-019-09361-0

77. Brand DD, Latham KA, Rosloniec EF. Collagen-Induced Arthritis. Nat Protoc (2007) 2:1269-75. doi: 10.1038/nprot.2007.173

78. Pöllinger B, Junt T, Metzler B, Walker UA, Tyndall A, Allard C, et al. Th17 Cells, Not IL-17+ $\gamma \delta$ T Cells, Drive Arthritic Bone Destruction in Mice and Humans. J Immunol (2011) 186:2602-12. doi: 10.4049/jimmunol. 1003370

79. Harnett MM, Harnett W, Pineda MA. The Parasitic Worm Product ES-62 Up-Regulates IL-22 Production by $\gamma \delta \mathrm{T}$ Cells in the Murine Model of Collagen-Induced Arthritis. Inflamm Cell Signal (2014) 1:e308-26. doi: $10.14800 /$ ics. 308

80. Doonan J, Lumb FE, Pineda MA, Tarafdar A, Crowe J, Khan AM, et al. Protection Against Arthritis by the Parasitic Worm Product ES-62, and Its Drug-Like Small Molecule Analogues, Is Associated With Inhibition of Osteoclastogenesis. Front Immunol (2018) 9:1016. doi: 10.3389/ fimmu.2018.01016

81. Rodgers DT, McGrath MA, Pineda MA, Al-Riyami L, Rzepecka J, Lumb F, et al. The Parasitic Worm Product ES-62 Targets Myeloid Differentiation Factor 88-Dependent Effector Mechanisms to Suppress Antinuclear Antibody Production and Proteinuria in MRL/lpr Mice. Arthritis Rheumatol (2015) 67:1023-35. doi: 10.1002/art.39004

82. Aprahamian TR, Zhong X, Amir S, Binder CJ, Chiang L-K, Al-Riyami L, et al. The Immunomodulatory Parasitic Worm Product ES-62 Reduces Lupus-Associated Accelerated Atherosclerosis in a Mouse Model. Int J Parasitol (2015) 45:203-7. doi: 10.1016/j.ijpara.2014.12.006

83. Wilson EH, Deehan MR, Katz E, Brown KS, Houston KM, O’Grady J, et al. Hyporesponsiveness of Murine B Lymphocytes Exposed to the Filarial Nematode Secreted Product ES-62 In Vivo. Immunology (2003) 109:23845. doi: 10.1046/j.1365-2567.2003.01661.x

84. Rzepecka J, Siebeke I, Coltherd JC, Kean DE, Steiger CN, Al-Riyami L, et al. The Helminth Product, ES-62, Protects Against Airway Inflammation by Resetting the Th Cell Phenotype. Int J Parasitol (2013) 43:211-23. doi: 10.1016/j.ijpara.2012.12.001

85. McSorley HJ, O'Gorman MT, Blair N, Sutherland TE, Filbey KJ, Maizels RM. Suppression of Type 2 Immunity and Allergic Airway Inflammation by Secreted Products of the Helminth Heligmosomoides Polygyrus. Eur J Immunol (2012) 42:2667-82. doi: 10.1002/eji.201142161

86. Navarro S, Pickering DA, Ferreira IB, Jones L, Ryan S, Troy S, et al. Hookworm Recombinant Protein Promotes Regulatory T Cell Responses That Suppress Experimental Asthma. Sci Trans Med (2016) 8:362ra143. doi: 10.1126/scitranslmed.aaf8807

87. Coltherd JC, Rodgers DT, Lawrie RE, Al-Riyami L, Suckling CJ, Harnett W, et al. The Parasitic Worm-Derived Immunomodulator, ES-62 and Its DrugLike Small Molecule Analogues Exhibit Therapeutic Potential in a Model of Chronic Asthma. Sci Rep (2016) 6:19224. doi: 10.1038/srep19224

88. Suckling CJ, Mukherjee S, Khalaf AI, Narayan A, Scott FJ, Khare S, et al. Synthetic Analogues of the Parasitic Worm Product ES-62 Reduce Disease Development in In Vivo Models of Lung Fibrosis. Acta Trop (2018) 185:2128. doi: 10.1016/j.actatropica.2018.05.015

89. Crowe J, Lumb FE, Doonan J, Broussard M, Tarafdar A, Pineda MA, et al. The Parasitic Worm Product ES-62 Promotes Health- and Life-Span in a High Calorie Diet-Accelerated Mouse Model of Ageing. PloS Pathog (2020) 16:e1008391. doi: 10.1371/journal.ppat.1008391

90. Lumb FE, Crowe J, Doonan J, Suckling CJ, Selman C, Harnett MM, et al. Synthetic Small Molecule Analogues of the Immunomodulatory Acanthocheilonema Viteae Product ES-62 Promote Metabolic Homeostasis During Obesity in a Mouse Model. Mol Biochem Parasitol (2019) 234:111232. doi: 10.1016/j.molbiopara.2019.111232

91. Doonan J, Thomas D, Wong MH, Ramage HJ, Al-Riyami L, Lumb FE, et al. Failure of the Anti-Inflammatory Parasitic Worm Product ES-62 to Provide Protection in Mouse Models of Type I Diabetes, Multiple Sclerosis, and 
Inflammatory Bowel Disease. Molecules (2018) 23:2669-82. doi: 10.3390/ molecules 23102669

92. Pluijmert NJ, de Jong RCM, de Vries MR, Pettersson K, Atsma DE, Jukema JW, et al. Phosphorylcholine Antibodies Preserve Cardiac Function and Reduce Infarct Size by Attenuating the Post-Ischemic Inflammatory Response. JACC Basic Transl Sci (2020) 5:1228-39. doi: 10.1016/ j.jacbts.2020.09.012

93. de Vries MR, Ewing MM, de Jong RCM, MacArthur MR, Karper JC, Peters $\mathrm{EAB}$, et al. Identification of IgG1 Isotype Phosphorylcholine Antibodies for the Treatment of Inflammatory Cardiovascular Diseases. J Intern Med (2021) 290:141-56. doi: 10.1111/joim.13234

94. Frostegård J, Tao W, Råstam L, Lindblad U, Lindeberg S. Antibodies Against Phosphorylcholine Among New Guineans Compared to Swedes: An Aspect of the Hygiene/Missing Old Friends Hypothesis. Immunol Invest (2017) 46:59-69. doi: 10.1080/08820139.2016.1213279

95. Su J, Hua X, Concha H, Svenungsson E, Cederholm A, Frostegård J. Natural Antibodies Against Phosphorylcholine as Potential Protective Factors in SLE. Rheumatology (Oxford) (2008) 47:1144-50. doi: 10.1093/rheumatology/ ken 120

96. Thiagarajan D, Fiskesund R, Frostegård A, Steen J, Rahman M, Vikström M, et al. Immunoglobulin G1 Antibodies Against Phosphorylcholine Are Associated With Protection in Systemic Lupus Erythematosus and Atherosclerosis: Potential Underlying Mechanisms. ACR Open Rheumatol (2020) 2:344-56. doi: 10.1002/acr2.11127

97. López P, Rodríguez-Carrio J, Martínez-Zapico A, Pérez-Álvarez ÁI, Benavente L, Caminal-Montero L, et al. IgM Anti-Phosphorylcholine Antibodies Associate With Senescent and IL-17+ T Cells in SLE Patients With a Pro-Inflammatory Lipid Profile. Rheumatology (2019) 59:407-17. doi: 10.1093/rheumatology/kez264

98. Sun J, Lundström SL, Zhang B, Zubarev RA, Steuer J, Gillgren P, et al. IgM Antibodies Against Phosphorylcholine Promote Polarization of $\mathrm{T}$ Regulatory Cells From Patients With Atherosclerotic Plaques, Systemic Lupus Erythematosus and Healthy Donors. Atherosclerosis (2018) 268:3648. doi: 10.1016/j.atherosclerosis.2017.11.010

99. Thiagarajan D, Oparina N, Lundström S, Zubarev R, Sun J, Beretta L, et al. IgM Antibodies Against Malondialdehyde and Phosphorylcholine in Different Systemic Rheumatic Diseases. Sci Rep (2020) 10:11010. doi: 10.1038/s41598-020-66981-z

100. Ståhle M, Silvola JMU, Hellberg S, de Vries M, Quax PHA, Kroon J, et al. Therapeutic Antibody Against Phosphorylcholine Preserves Coronary Function and Attenuates Vascular (18)F-FDG Uptake in Atherosclerotic Mice. JACC Basic Transl Sci (2020) 5:360-73. doi: 10.1016/j.jacbts. 2020.01.008

101. Que X, Hung M-Y, Yeang C, Gonen A, Prohaska TA, Sun X, et al. Oxidized Phospholipids Are Proinflammatory and Proatherogenic in Hypercholesterolaemic Mice. Nature (2018) 558:301-6. doi: 10.1038/ s41586-018-0198-8

102. Lobo PI, Schlegel KH, Bajwa A, Huang L, Okusa MD. Natural IgM and TLR Agonists Switch Murine Splenic Pan-B to "Regulatory" Cells That Suppress Ischemia-Induced Innate Inflammation via Regulating NKT-1 Cells. Front Immunol (2017) 8. doi: 10.3389/fimmu.2017.00974

103. Holodick NE, Tumang JR, Rothstein TL. Immunoglobulin Secretion by B1 Cells: Differential Intensity and IRF4-Dependence of Spontaneous IgM Secretion by Peritoneal and Splenic B1 Cells. Eur J Immunol (2010) 40:3007-16. doi: 10.1002/eji.201040545

104. Prieto JMB, Felippe MJB. Development, Phenotype, and Function of NonConventional B Cells. Comp Immunol Microbiol Infect Dis (2017) 54:38-44. doi: 10.1016/j.cimid.2017.08.002
105. Bhat NM, Kantor AB, Bieber MM, Stall AM, Herzenberg LA, Teng NNH. The Ontogeny and Functional Characteristics of Human B-1 (CD5+ B) Cells. Int Immunol (1992) 4:243-52. doi: 10.1093/intimm/4.2.243

106. Haury M, Sundblad A, Grandien A, Barreau C, Coutinho A, Nobrega A. The Repertoire of Serum IgM in Normal Mice Is Largely Independent of External Antigenic Contact. Eur J Immunol (1997) 27:1557-63. doi: 10.1002/ eji. 1830270635

107. Masmoudi H, Mota-Santos T, Huetz F, Coutinho A, Cazenave P-A. All T15 Id-Positive Antibodies (But Not the Majority of VHT15+ Antibodies) Are Produced by Peritoneal CD5+ B Lymphocytes. Int Immunol (1990) 2:51520. doi: $10.1093 /$ intimm/2.6.515

108. Wilson EH, Katz E, Goodridge HS, Harnett MM, Harnett W. In Vivo Activation of Murine Peritoneal B1 Cells by the Filarial Nematode Phosphorylcholine-Containing Glycoprotein ES-62. Parasite Immunol (2003) 25:463-6. doi: 10.1111/j.1365-3024.2003.00650.x

109. Ackerman CJ, Harnett MM, Harnett W, Kelly SM, Svergun DI, Byron O. $19 \AA$ Solution Structure of the Filarial Nematode Immunomodulatory Protein, ES-62. Biophys J (2003) 84:489-500. doi: 10.1016/S0006-3495(03) 74868-1

110. Egan CA, Houston KM, Alcocer MJC, Solovyova A, Tate R, Lochnit G, et al. Lack of Immunological Cross-Reactivity Between Parasite-Derived and Recombinant Forms of Es-62, a Secreted Protein of Acanthocheilonema Viteae. Parasitology (2006) 132:263-74. doi: 10.1017/S0031182005009005

111. Harnett W, Rzepecka J, Houston KM. How do Nematodes Transfer Phosphorylcholine to Carbohydrates? Trends Parasitol (2010) 26:114-8. doi: $10.1016 / j . p t .2009 .12 .003$

112. McVeigh P, Maule AG. Can CRISPR Help in the Fight Against Parasitic Worms? eLife (2019) 8:e44382. doi: 10.7554/eLife.44382

113. Ball DH, Al-Riyami L, Harnett W, Harnett MM. IL-33/ST2 Signalling and Crosstalk With Fceri and TLR4 Is Targeted by the Parasitic Worm Product, ES-62. Sci Rep (2018) 8:4497. doi: 10.1038/s41598-018-22716-9

114. Lochnit G, Bongaarts R, Geyer R. Searching New Targets for Anthelminthic Strategies: Interference With Glycosphingolipid Biosynthesis and Phosphorylcholine Metabolism Affects Development of Caenorhabditis Elegans. Int J Parasitol (2005) 35:911-23. doi: 10.1016/j.ijpara.2005.02.015

115. Houston KM, Sutharsan R, Steiger CN, Schachter H, Harnett W. Gene Inactivation Confirms the Identity of Enzymes Involved in Nematode Phosphorylcholine-N-Glycan Synthesis. Mol Biochem Parasitol (2008) 157:88-91. doi: 10.1016/j.molbiopara.2007.08.009

Conflict of Interest: The authors declare that the research was conducted in the absence of any commercial or financial relationships that could be construed as a potential conflict of interest.

Publisher's Note: All claims expressed in this article are solely those of the authors and do not necessarily represent those of their affiliated organizations, or those of the publisher, the editors and the reviewers. Any product that may be evaluated in this article, or claim that may be made by its manufacturer, is not guaranteed or endorsed by the publisher.

Copyright $\odot 2021$ Buitrago, Duncombe-Moore, Harnett and Harnett. This is an openaccess article distributed under the terms of the Creative Commons Attribution License (CC BY). The use, distribution or reproduction in other forums is permitted, provided the original author(s) and the copyright owner(s) are credited and that the original publication in this journal is cited, in accordance with accepted academic practice. No use, distribution or reproduction is permitted which does not comply with these terms. 